\title{
Integrating Agronomic Practices for the Mitigation of Crack Formation on Sweet Potato Roots at Umudike, South Eastern Nigeria
}

\author{
Onunka, N.A. ${ }^{1, *}$, Njoku, J.C. ${ }^{1}$, Ehisianya, C.N. ${ }^{2}$ \\ ${ }^{1}$ National Root Crops Research Institute, KM 8 Umuahia-Ikot Ekpene Road, Umudike Abia State, Nigeria \\ ${ }^{2}$ Michael Okpara University of Agriculture, Umudike, Nigeria
}

Copyright $(2017$ by authors, all rights reserved. Authors agree that this article remains permanently open access under the terms of the Creative Commons Attribution License 4.0 International License

\begin{abstract}
Field experiment was conducted in 2013 cropping season to evaluate the effect of integrating different agronomic practices for mitigating crack formation on sweet potato (Ipomoea batatas) roots. Cracks are malformations on the edible roots of sweet potato which make them look unattractive, form portals for disease and pest invasion, lead to decay and high peeling loss, and reduce marketability and acceptability. The agronomic practices evaluated included; two nutrient sources NPK 20:10:10 and 15:15:15, four different harvest periods 3, 4, 5, and 6 months after planting (MAP) on the three varieties of sweet potato namely TIS87/0087, UMUSPO/1 and CIP440293. It was carried out at the Eastern farm of National Root Crops Research Institute Umudike Abia State which lies between latitude $4^{0} 15^{1}$ and $7^{0} \mathrm{~N}$ and longitude $15^{0} 29^{1} \mathrm{~N}$ and $7^{0} 33^{1} \mathrm{E}$ at an elevation of $122 \mathrm{~m}$ above sea level. The experimental design was a split plot arrangement fitted into a randomized complete block design, main plot was nutrient source, subplot was time of harvest, and sub subplot was variety. There were thirty six treatments replicated three times. The soil was classified as sandy loam. Data were collected on number of roots with cracks, total root number, total root fresh weight, and rot incidence. Results showed that the effect of the nutrient sources was not statistically significant at $(\mathrm{P} \leq 0.05)$ on crack formation more cracks were recorded on varieties UMUSPO/1 and CIP440293 (orange-fleshed) than TIS87/0087 (white-fleshed). Time of harvest was very highly significant $(\mathrm{P}<0.001)$ on number of roots with cracks. From this work it can be concluded that time of harvest and variety played important roles in the formation of the cracks in the tuberous roots of sweet potato which reduce the quality of the crop. The type of fertilizer used has no effect on the crack formations, root size and number while early harvest is recommended.
\end{abstract}

Keywords Agronomic Practices, Crack Formation, Sweet Potato Roots

\section{Introduction}

Sweet potato originated from tropical Central America. Botanically, the underground part is classified as a storage root, rather than a tuber, as in the white ("Irish") potato (Solanum tuberosum). Currently, sweet potato is cultivated in more than 100 countries, mostly throughout tropical and subtropical Asia. The Sweet potato is a perennial, although it is grown as an annual. It belongs to the morning glory family or Convolvulaceae. Large, fleshy, edible storage roots are formed on the underground stem nodes. Latex occurs in all parts of the plant. It is a perennial herb cultivated as an annual, with trailing or twining stems up to $4 \mathrm{~m}$ long, which sends roots into the soil at the nodes. The general form of the leaf is heart-shaped or halberd-shaped. The flowers have purplish throats and white margins, resembling those of the morning glory. The blooms are rare and may not produce seed.

The edible roots are also variable in shape, size and colour. Some are long and cylindrical, others short, thick and rounded at the ends. The skin may be whitish, dull straw-coloured, light red or purple. The flesh is also variable in colour, texture, moisture, and quality. Classification of varieties is usually based upon the shape of the leaves.

There are two broad categories of sweet potato: The staple type with white flesh and white or purple skin has a high starch and dry- matter content. The dessert type has orange flesh and orange skin with a high sugar and beta-carotene content.

As a result of the importance of the crop efforts are on top gear to increase the production and utilization, but a lot of problems militate against its production. Some of these include soil fertility, pests and diseases, malformations or cracks on the edible roots, etc. Some of the maturity indices of the crop are senescence, and at times cracks on the surface 
of the roots at maturity which is usually referred to as maturity cracks but it has recently been observed that both mature and immature roots of many varieties develop these malformations or cracks on their root surfaces Fig 1. These cracks or malformations make the roots unattractive, with the resultant low market values. The cracks also form portals for pest and disease invasion and leading to decay. If eventually these roots are sold buyers complain of high peeling losses. The cracks are also believed to alter the tastes and reduce acceptability. In choosing sweet potato for storage are those that are firm and do not have any cracks or soft spots [1]. Some schools of thought believe that scientists have not yet determined the conditions that lead to cracking of sweet potato roots. In some varieties it appears to be an inherited characteristic believed to be controlled through crop rotation [2]. Several agronomic practices using nutrients have been employed to increase and improve the production of the crop for example [3], investigated the effect of organic and inorganic manures and their time of application on the soil property and yield of sweet potato and made recommendations on how to increase the root yield.

In [4] investigated the varietal response of the crop to different to nitrogen fertilization, [5] also investigated the effect of nutrient application on the crop establishment and root yield. [6] reported the effect of organic manure on the growth and yield of sweet potato, [7] reported the performance of introduced and locally bred genotypes in multi agro ecological zone all in the bid to improve the yield. However, there is a dearth of information on the possible causes of the mal formation or the cracks observed on the surface of the tuberous roots of the different varieties at or before maturity period. Therefore, there was a need to try different agronomic practices with a view to finding possible causes and mitigation measures using these practices.

The objective of this research is to evaluate the use of a combination of some of these agronomic practices to mitigate the formation of cracks on the tuberous roots of sweet potato varieties as well as on the other yield parameters of the crop.

\section{Materials and Methods}

\subsection{The Description of the Study Area}

The research trial was conducted at bock C5 of Eastern farm of National Root Crops Research institute Umudike. Umudike is located on latitude $4^{\circ} 15^{1}$ and $7^{\circ} \mathrm{N}$ and longitude $52^{0} 91 \mathrm{~N}$ and $7^{\circ} 33^{1} \mathrm{E}$ of the equator with an elevation of $122 \mathrm{~m}$ above sea level. The site of the experiment was slashed, ploughed, harrowed and ridged .The block used for this research work was maintained in a two year rotation but in the penultimate year the block was planted with cassava and fertility enhanced by inorganic fertilizer. The dominant weed on the land before clearing was Panicum maximum. Soil samples were randomly collected with soil auger prior to planting at a depth of $0-15 \mathrm{~cm}$. All the soils were thoroughly mixed and a composite sample was obtained and analyzed for the physco- chemical properties.

Sample Soil Preparation: The soil samples were air dried and ground to pass through $2 \mathrm{~mm}$ sieve. The samples for analysis for organic carbon, and total nitrogen were further ground and sieved through $0.5 \mathrm{~mm}$ mesh.

Particle size distribution: Particle size distribution was determined by hydrometer method of Juo (1979) . Soil samples were dispersed using $5 \%$ sodium hexameta phosphate solution and steering the soil suspension for 15 mins with a multi mix machine based on gravitational sedimentation governed by stokes law. The hydrometer was used to measure the concentration of sand silt and clay.

Determination of $\mathbf{P}^{\mathbf{H}}$ : This was determined on 2: 1 soil water suspension using E.EL glass electrode meter Mcleans (1965).

Determination of Organic Carbon: This was determined by Wakley and Black (1934) wet oxidation as modified and described by Juo (1979). Organic carbon was oxidized by potassium dichromate in the presence of concentrated sulphuric acid and titrated with ferrous ammonium sulphate. The value for organic matter was obtained by multiplying the organic carbon values by 1.724 (Van Bemelin factor) based on the fact that organic carbon contains $58 \%$ carbon.

Exchangeable Cation: These were determined by extracting the samples with neutral normal ammonium acetate. Exchangeable calcium and magnesium were determined by the EDTA titration method of Juo (1979) while potassium and sodium leachate were read using EEL flame photometer. The exchangeable acidity was determined by extracting $5 \mathrm{~g}$ of the soil with $1 \mathrm{NKCL}$ and titrating with $0.5 \mathrm{~g}$ of the soil with INKCI and titrating with $0.5 \mathrm{~N} \mathrm{NaoH}$ using phenolphthalein indicator Kemprath (1967). Effective Cation Exchange Capacity (ECEC) was taken as the sum of the exchangeable cation $\left(\mathrm{Ca}^{2+}+\mathrm{Na}^{+}+\mathrm{K}^{+}+\mathrm{Mg}^{2+}\right)$ and the exchangeable acidity. The percentage base saturation was calculated as follows:

$$
\% \text { Base Saturation }=\frac{\mathrm{Ca}^{2+}+\mathrm{Na}^{+}+\mathrm{K}^{+}+\mathrm{Mg}^{2+} \times 100}{E C E C}
$$

Total Nitrogen: The total Nitrogen was determined by Micro Kjedahl method of Bremner (1965). Nitrogen in the soil sample was converted to ammonium sulphate by digesting the sample with concentrated sulphuric acid in the presence of catalyst mixture. The ammonium liberated by the distillation of the digest with sodium hydroxide was collected in 5\% boric acid with mixed indicator solution and titrated with standard hydrochloric acid the result obtained is as shown on Table 1 . The soil is moderately acidic high in organic matter with appreciable percentage base saturation and classified sandy loam.

\subsection{The Climatic Weather Condition during the Field Experimentation}

The climatic weather condition during the field experimentation is shown in table 2. The most important factors that affect crop growth generally including sweet 
potato include rainfall, temperature, relative humidity and sunshine record amongst others. In the experimental area, the temperature was high and changed only slightly during the year. The highest temperature was recorded in February but reduced from March with the lowest at August and rising again in December. The maximum temperature was $30.75^{\circ} \mathrm{c}$ and a minimum of $21.58^{\circ} \mathrm{c}$. There was a total rainfall of $2098.6 \mathrm{~mm}$ in 138 days with a mean of $174.88 \mathrm{~mm}$ in 11.5 days. The highest rainfall was recorded in August with non in January and the least in February. The relative humility was generally high ranging from 63 to $75 \%$. The least relative humidity values were recorded during the dry season months of January and February this is usually during the harmatan. During this period, dry dusty wind blows across the area and causes occasional reduction in relative humidity.

The sunshine hour record was by modal rising from January to June and again from August to December totaling $44.9 \mathrm{hrs}$ with a mean of $3.74 \mathrm{hrs}$. The weather data of the experimental year 2013 did not defer from the 42 years long term average of the area (though not published in this work). This tends to indicate that the crack formations observed on the sweet potato roots may not have been as a result of the climatic change.

\subsection{Experimental Design}

The experimental design was Randomized Complete Block in a split-split plot fashion. Four node cuttings of each of the three varieties were used for planting. Two nodes were inserted into the soil. A planting distance of $30 \mathrm{~cm}$ between plants and $1 \mathrm{~m}$ between the ridges was used giving a population of 60 plants per plot and 33,333 plant ha ${ }^{1 .}$ The main plot size was $18 \mathrm{~m} \mathrm{x} 12 \mathrm{~m}$ while subplot size was $6 \mathrm{~m} \mathrm{x}$ $3 \mathrm{~m}$. Main plot consisted of fertilizer types, namely NPK 20:10:10 and 15:15:15 designated $F_{1}$ and $F_{2}$ with control as $F_{0}$. The subplot was the time of harvest designated $T_{1}, T_{2}, T_{3}$ and $\mathrm{T}_{4}$ for harvests at $3,4,5$ and 6 , months after planting (MAP) while the sub-sub plot was the varieties designated $\mathrm{V}_{1}, \mathrm{~V}_{2}$, and $\mathrm{V}_{3}$ for TIS87/0087, UMUSPO/1 and CIP440293.

There were three main plots in each replicate with twelve sub plots replicated three times giving a total of one hundred and eight plots. After planting of the four node cuttings gap filling was done to supply the vines that could not sprout. Weeding was manually carried out two weeks after planting before the sweet potato cover completely suppressed the weeds that lasted till harvest. There was no severe incidence of pest on the foliage so no pesticide was applied. Fertilizer was applied at 4 weeks after planting (WAP) according to [8]. The experiment was harvested as indicated in the design.

\subsection{Data Collection}

Data were taken on number of roots with cracks, total root weight with and without cracks, total root number, and rot incidence of the roots harvested from the entire (gross) plot. Data collected were subjected to statistical analysis using
Genstat [9].

\section{Results and Discussion}

\subsection{Number of Roots}

The effect of some agronomic practices on the number of roots with cracks of three Sweet potato varieties is shown on Table 1. The result showed that more numbers of roots with cracks were recorded during the last harvest period $\mathrm{T}_{4}$, across the three varieties and the two nutrient types $F_{1}$ and $F_{2}$. This was followed by roots harvested at $\mathrm{T}_{4}$. The least numbers of roots with cracks were recorded at $T_{1}$. The control recorded the least number of cracks during harvest at $\mathrm{T}_{1}$ and in $\mathrm{T}_{3}$, while in $\mathrm{T}_{2}$, the control had higher number of roots with cracks. Time of harvest was very highly significant $(\mathrm{P} \leq 0.001)$ across all the varieties while the interactions were not. Variety $2 \mathrm{~V}_{2}$ (UMUSPO/1) had the highest mean number of roots with cracks 5.39, followed by $\mathrm{V}_{3}$ (CIP440293) 2.31, whereas the least was recorded on $\mathrm{V}_{1}$ (TIS87/0078) 1.72 .

More roots with cracks were recorded across all the three varieties where NPK 20:10:10 was applied than where NPK 15:15:15 was applied. The variation on the number of cracks recorded in this research could be attributed to varietal differences for which sweet potato is known [4]. Variety 1, TIS87/0087 where the least number of cracks was recorded is white fleshed while varieties 2 and 3 are orange fleshed varieties. From this work the orange fleshed varieties can be said to be more susceptible to crack formation than the white fleshed. According to [10] soils high in organic matter may result in rough cracked jumbo sized roots the cracks observed here can in part be attributed to the fairly high organic matter in the soil

\subsection{Total Root Weight}

The result of the effect of some agronomic practices on the mitigation of cracks on the roots of three sweet potato varieties is shown on Table 4 . The result showed that the total root weight across the three varieties increased as time of harvest increased $\mathrm{T}_{1}$ to $\mathrm{T}_{4}$. The effect of time of harvest on total root weight was statistically very highly significant $(\mathrm{P}<$ 0.001 ). The lower yield recorded at $T_{1}$ could be that the nutrient supplied had not become available to the crops as it was applied at $T_{2}$ as recommended for the crop [7]. More root yields was recorded with the application of $\left(\mathrm{F}_{2}\right)$ NPK 15:15:15 than $\left(F_{1}\right)$ NPK 20:10:10. This result is in line with findings [11] that different varieties of sweet potato require different types of nutrient sources. The effect of nutrient type on the total root weight was very highly significant $(\mathrm{P}<0.001)$. The root yield across the three varieties were in the range of $V_{1}>V_{2}>V_{3}$. The interaction between the type of fertilizer used, and the variety were also significant $(\mathrm{P}<0.005)$ while the interaction between time, type of fertilizer and 
variety and type of fertilizer variety and time were not significant.

\subsection{Total Root Number}

The result of the effect of some agronomic practices on the total root number of three varieties of Sweet potato is shown on Table 4. The result showed that the highest number of roots was recorded at $\left(\mathrm{F}_{0}\right)$ the control. This is expected as absence of nutrient results in production of small sized roots or roots less than $100 \mathrm{~g}$ usually more in number than the saleable ones. The result also showed that variety was very highly significant $(\mathrm{P}<0.001)$. Variety 2. UMUSPO/1 recorded the highest total mean root number (39.53) followed by variety 1 TIS $87 / 0087$ and lastly variety 3 , CIP440293. The effect of time of fertilizer application and the type of fertilizer were not significant on the total root number; however the highest mean root number was recorded at $\mathrm{T}_{2}$ though not significantly different from the rest. It is said that deeply ploughed soils create an environment or the tendency for roots to grow slender and long hence the larger number of small roots whereas on very rich soils the crops produce too much vines and the potatoes are likely to be too large. This can be said to be the situation here as the soil is not rich see Table 2 .

\subsection{Rot Incidence}

The result of different agronomic practices on the rot incidence of three varieties of sweet potato is shown on Table 6 . The result showed that time and of harvest variety were highly significant $(\mathrm{P}<0.05)$ on the rot incidence. The result also showed that the incidence of rot was recorded within $T_{3}$ and $T_{4}$. Harvests at $T_{1}$ and $T_{2}$ recorded zero rot. The highest number of rot was recorded on variety $2(0.42)$ followed by $V_{3}$ and finally by $V_{1}$. Fertilizer type had no significant effect on the rot incidence of the three varieties, however NPK 20:10:10 induced more rot across all the varieties with a mean number of 1.00 and 0.78 . All rots recorded were dry. Rots are common diseases of root crops including sweet potato usually caused by such organisms as Rhizopus spp, Fusarium spp and nematodes.

Table 1. Some physical and chemical properties of the soil of the study area

\begin{tabular}{|c|c|c|c|}
\hline Property & Values & Property & Values \\
\hline \%Sand & 78.6 & $\mathrm{Ca}\left(\mathrm{cmolkg}^{1}\right)$ & 2.00 \\
\cline { 2 - 4 } \%Silt & 7.4 & $\mathrm{pH}\left(\mathrm{H}_{2} \mathrm{O}\right)$ & 4.5 \\
\hline \%Clay & 14.00 & $\mathrm{~K}\left(\mathrm{cmolkg}^{1}\right)$ & 0.0036 \\
\%OM & 2.26 & $\mathrm{Na}\left(\mathrm{cmo} \mathrm{kg}^{-1}\right)$ & 0.072 \\
\%OC & 0.042 & ECEC & 4.75 \\
$\% \mathrm{Ca}$ & 1.31 & $\% \mathrm{BS}$ & 69.26 \\
\end{tabular}

Table 2. Climatic Weather Data of the Experimental Area

\begin{tabular}{|c|c|c|c|c|c|c|c|}
\hline \multicolumn{3}{|c|}{ Temperature $^{0} \mathrm{c}$} & \multicolumn{2}{|c|}{ Rainfall(mm) } & \multicolumn{2}{|c|}{ Relative Humility( \%) } & \multirow{2}{*}{$\frac{\text { Sunshine }(\mathrm{Hrs})}{\text { sun shine }}$} \\
\hline MONTH & Max. & Min. & Days & Rainfall & 0900hHrs & $1500 \mathrm{Hrs}$ & \\
\hline JAN & 32 & 20 & 2 & 0 & 63 & 46 & 3.6 \\
\hline FEB & 34 & 22 & 3 & 43.7 & 72 & 50 & 5.2 \\
\hline MAR & 32 & 20 & 8 & 138.8 & 76 & 62 & 4.2 \\
\hline APR & 32 & 22 & 9 & 78.7 & 78 & 65 & 5.7 \\
\hline MAY & 29 & 22 & 16 & 249.2 & 83 & 69 & 4.9 \\
\hline JUN & 30 & 22 & 14 & 281.8 & 84 & 78 & 4.2 \\
\hline JUL & 29 & 22 & 12 & 144.4 & 87 & 76 & 2.7 \\
\hline AUG & 28 & 22 & 18 & 444.2 & 79 & 68 & 1.5 \\
\hline SEP & 29 & 22 & 22 & 405.3 & 74 & 70 & 2 \\
\hline OCT & 30 & 22 & 16 & 165.1 & 84 & 73 & 3.5 \\
\hline NOV & 32 & 22 & 10 & 147.4 & 81 & 89 & 3.5 \\
\hline DEC & 32 & 21 & 8 & 0 & 75 & 60 & 3.9 \\
\hline Total & 369 & 259 & 138 & 2098.6 & 936 & 806 & 44.9 \\
\hline Mean & 30.75 & 21.5 & 11.5 & 174.88 & 78 & 67.17 & 3.74 \\
\hline
\end{tabular}

Source: Agromet and Statistical Unit, NRCRI Umudike 2013 
Table 3. The effect of some agronomic practices on the number of roots with crack formation on the three varieties of sweet potato

\begin{tabular}{|c|c|c|c|c|c|}
\hline \multirow{2}{*}{ Time } & \multirow{2}{*}{$\begin{array}{l}\text { Fert. } \\
\text { Type }\end{array}$} & \multicolumn{4}{|c|}{ Varieties } \\
\hline & & $\mathrm{V}_{1}$ & $\mathrm{~V}_{2}$ & $\mathrm{~V}_{3}$ & Mean \\
\hline \multirow[t]{3}{*}{$\mathrm{T}_{1}$} & $\mathrm{~F}_{0}$ & 0.33 & 3.33 & 0.67 & 1.44 \\
\hline & $\mathrm{F}_{1}$ & 3.67 & 5.00 & 1.00 & 3.22 \\
\hline & $\mathrm{F}_{2}$ & 1.00 & 2.67 & 1.00 & 1.56 \\
\hline \multirow[t]{3}{*}{$\mathrm{T}_{2}$} & $\mathrm{~F}_{0}$ & 3.67 & 5.33 & 5.67 & 4.89 \\
\hline & $\mathrm{F}_{1}$ & 2.67 & 11.00 & 3.67 & 5.78 \\
\hline & $\mathrm{F}_{2}$ & 3.33 & 7.67 & 1.67 & 4.22 \\
\hline \multirow[t]{3}{*}{$\mathrm{T}_{3}$} & $\mathrm{~F}_{0}$ & 0.00 & 2.33 & 2.00 & 1.44 \\
\hline & $\mathrm{F}_{1}$ & 0.00 & 6.00 & 0.67 & 2.22 \\
\hline & $\mathrm{F}_{2}$ & 0.00 & 3.33 & 0.00 & 1.11 \\
\hline \multirow[t]{3}{*}{$\mathrm{T}_{4}$} & $\mathrm{~F}_{0}$ & 1.33 & 7.33 & 3.00 & 3.89 \\
\hline & $\mathrm{F}_{1}$ & 0.33 & 4.33 & 3.67 & 2.78 \\
\hline & $\mathrm{F}_{2}$ & 4.33 & 6.33 & 4.67 & 5.11 \\
\hline Mean & & 1.72 & 5.39 & 2.31 & \\
\hline \multirow[t]{3}{*}{ SED } & Time & 1.135 & & & \\
\hline & $\begin{array}{l}\text { Fert. } \\
\text { Type }\end{array}$ & 0.983 & & & \\
\hline & Var. & 0.983 & & & \\
\hline
\end{tabular}

Table 4. The effect of some agronomic practices on total root number of three varieties of sweet potato

\begin{tabular}{|c|c|c|c|c|c|}
\hline \multirow{2}{*}{ Time } & \multirow{2}{*}{$\begin{array}{c}\text { Fert. } \\
\text { Type }\end{array}$} & \multicolumn{4}{|c|}{ Varieties } \\
\cline { 3 - 6 } & $\mathrm{V}_{1}$ & $\mathrm{~V}_{2}$ & $\mathrm{~V}_{3}$ & Mean \\
\hline $\mathrm{T}_{1}$ & $\mathrm{~F}_{0}$ & 5.87 & 8.73 & 3.53 & 6.04 \\
\hline & $\mathrm{F}_{1}$ & 8.40 & 8.23 & 2.20 & 6.28 \\
\hline & $\mathrm{F}_{2}$ & 8.47 & 5.53 & 5.03 & 6.34 \\
\hline $\mathrm{T}_{2}$ & $\mathrm{~F}_{0}$ & 14.53 & 12.13 & 11.37 & 12.68 \\
\hline & $\mathrm{F}_{1}$ & 12.67 & 15.87 & 9.03 & 12.52 \\
\hline & $\mathrm{F}_{2}$ & 15.70 & 22.20 & 9.20 & 15.70 \\
\hline $\mathrm{T}_{3}$ & $\mathrm{~F}_{0}$ & 12.67 & 20.97 & 9.17 & 14.27 \\
\hline & $\mathrm{F}_{1}$ & 12.57 & 15.50 & 5.47 & 11.18 \\
\hline & $\mathrm{F}_{2}$ & 6.83 & 9.13 & 7.23 & 11.06 \\
\hline $\mathrm{T}_{4}$ & $\mathrm{~F}_{0}$ & 3.27 & 33.17 & 10.97 & 5.80 \\
\hline & $\mathrm{F}_{1}$ & 13.70 & 41.30 & 10.63 & 21.88 \\
\hline & $\mathrm{F}_{2}$ & 40.17 & 21.70 & 7.73 & 23.20 \\
\hline Mean & & 13.74 & 17.87 & 7.63 & \\
\hline SED & Time & 2.487 & & & \\
\hline & Fert. & 2.154 & & & \\
\hline & Vype & 2.154 & & & \\
\hline
\end{tabular}

Table 5. The effect of some agronomic practices on the total root weight of three varieties of sweet potato

\begin{tabular}{|c|c|c|c|c|c|}
\hline \multirow{2}{*}{ Time } & \multirow{2}{*}{$\begin{array}{l}\text { Fert. } \\
\text { Type }\end{array}$} & \multicolumn{4}{|c|}{ Varieties } \\
\hline & & $\mathrm{V}_{1}$ & $\mathrm{~V}_{2}$ & $\mathrm{~V}_{3}$ & Mean \\
\hline \multirow[t]{3}{*}{$\mathrm{T}_{1}$} & $\mathrm{~F}_{0}$ & 56.3 & 96.7 & 38.3 & 63.77 \\
\hline & $\mathrm{F}_{1}$ & 63.0 & 82.2 & 32.5 & 59.17 \\
\hline & $\mathrm{F}_{2}$ & 40.3 & 84.3 & 41.3 & 55.30 \\
\hline \multirow[t]{3}{*}{$\mathrm{T}_{2}$} & $\mathrm{~F}_{0}$ & 63.0 & 54.0 & 39.3 & 52.10 \\
\hline & $\mathrm{F}_{1}$ & 77.9 & 85.2 & 49.3 & 70.80 \\
\hline & $\mathrm{F}_{2}$ & 61.2 & 72.2 & 44.8 & 59.40 \\
\hline \multirow[t]{3}{*}{$\mathrm{T}_{3}$} & $\mathrm{~F}_{0}$ & 61.3 & 103.7 & 55.0 & 73.33 \\
\hline & $\mathrm{F}_{1}$ & 55.3 & 71.3 & 21.7 & 49.43 \\
\hline & $\mathrm{F}_{2}$ & 71.0 & 54.0 & 37.0 & 54.00 \\
\hline \multirow[t]{3}{*}{$\mathrm{T}_{4}$} & $\mathrm{~F}_{0}$ & 37.0 & 78.0 & 48.7 & 54.57 \\
\hline & $\mathrm{F}_{1}$ & 45.3 & 48.0 & 29.0 & 40.77 \\
\hline & $\mathrm{F}_{2}$ & 65.0 & 64.0 & 37.7 & 55.57 \\
\hline Mean & & 58.05 & 74.47 & 39.53 & \\
\hline \multirow[t]{3}{*}{ SED } & Time & 6.22 & & & \\
\hline & $\begin{array}{l}\text { Fert. } \\
\text { Type }\end{array}$ & 5.38 & & & \\
\hline & Var. & 5.38 & & & \\
\hline
\end{tabular}

Table 6. The effect of some Agronomic practices on rot incidence on three varieties of sweet potato

\begin{tabular}{|c|c|c|c|c|c|}
\hline \multirow{2}{*}{ Time } & \multirow{2}{*}{$\begin{array}{l}\text { Fert. } \\
\text { Type }\end{array}$} & \multicolumn{4}{|c|}{ Varieties } \\
\hline & & $\mathrm{V}_{1}$ & $\mathrm{~V}_{2}$ & $\mathrm{~V}_{3}$ & Mean \\
\hline \multirow[t]{3}{*}{$\mathrm{T}_{1}$} & $\mathrm{~F}_{0}$ & 0.000 & 0.000 & 0.000 & 0.00 \\
\hline & $\mathrm{F}_{1}$ & 0.000 & 0.000 & 0.000 & 0.00 \\
\hline & $\mathrm{F}_{2}$ & 0.000 & 0.000 & 0.000 & 0.00 \\
\hline \multirow[t]{3}{*}{$\mathrm{T}_{2}$} & $\mathrm{~F}_{0}$ & 0.000 & 0.000 & 0.000 & 0.00 \\
\hline & $\mathrm{F}_{1}$ & 0.000 & 0.000 & 0.000 & 0.00 \\
\hline & $\mathrm{F}_{2}$ & 0.000 & 0.000 & 0.000 & 0.00 \\
\hline \multirow[t]{3}{*}{$\mathrm{T}_{3}$} & $\mathrm{~F}_{0}$ & 0.000 & 0.333 & 1.000 & 0.44 \\
\hline & $\mathrm{F}_{1}$ & 0.000 & 1.333 & 0.000 & 0.44 \\
\hline & $\mathrm{F}_{2}$ & 0.000 & 0.667 & 0.333 & 1.00 \\
\hline \multirow[t]{3}{*}{$\mathrm{T}_{4}$} & $\mathrm{~F}_{0}$ & 0.333 & 1.000 & 0.667 & 0.67 \\
\hline & $\mathrm{F}_{1}$ & 0.000 & 0.000 & 1.000 & 0.33 \\
\hline & $\mathrm{F}_{2}$ & 0.000 & 1.667 & 0.667 & 0.778 \\
\hline Mean & & 0.03 & 0.42 & 0.31 & \\
\hline \multirow[t]{3}{*}{ SED } & Time & 0.821 & & & \\
\hline & $\begin{array}{l}\text { Fert. } \\
\text { Type }\end{array}$ & 0.1577 & & & \\
\hline & Var. & 0.1577 & & & \\
\hline
\end{tabular}




\section{Conclusions and Recommendation}

From this work, it can be concluded that time of harvest and variety played important roles in the formation of the cracks on the tuberous roots of sweet potato which reduce the quality of the crop. Types of fertilizer used had no effect on the crack formation, root size and number while orange fleshed varieties appear to be more susceptible. The climatic data within the period of the experiment did not show any significant change in the weather so the crack formations may not be attributed to weather variation It is further recommended that breeders should intensify efforts to identify the genes responsible for this incident for possible elimination. Further research with more white -fleshed varieties is recommended to confirm that orange fleshed varieties are susceptible.

\subsection{Acknowledgement}

The authors wish to acknowledge the magnanimity of the Executive Director and his management for providing the resources to carry out this work.

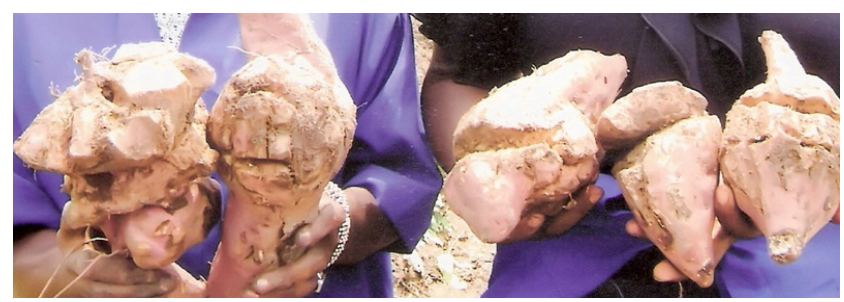

Figure 1. Some samples of the crack formations observed on the tuberous root of Sweet potato in the field

\section{REFERENCES}

[1] www.whfoods.org (2014)
[2] $\mathrm{A}$ and $\mathrm{M}$ agrolife extension, (www.aces.edu/pub/docs/A/ANR-0917 accessed 18/01/2016).

[3] Onunka N. A., Chukwu L. I., Mbanaso E. O., Ebeniro C. N. (2012). Effect of organic and inorganic manure and time of application on soil properties and yield of sweet potato in a Tropical Ultisol. Journal of Agriculture and Social Research, 2(2):

[4] Onunka N. A., Nwokocha H.N. (2003). Varietal Response of Sweet potato (Ipomoea batatas) to different levels of Nitrogen Fertilization in a Tropical Ultisol of South Eastern Nigeria Journal of Science and Tech, 2 (2):pp 436

[5] Onunka N. A., Osodeke V.O., Asawalam D.O., Ebeniro, C.N. (2011). Effect of Fertilizer Mixture and time of Application on crop Establishment and root yield of Sweet potato in an Ultisol of South Eastern Nigeria. Journal of Tropical Agriculture Food and Environment.10 (3): 22-27.

[6] Nwaigwe, G. O., Eka M.J., Nwankwo, I.I.M. (2013). Growth and Yield response of different sweet potato (Ipomoea batatas) to organic manure (Goat manure) in Umudike. Proceeding of the $47^{\text {th }}$ Annual Conference of Agricultural Society of Nigerian Ibadan 2013.

[7] Nwankwo, I.I.M., Afuepe, S.O., Nwaigwe G.O., Njoku J.C. (2013.) Performance of introduced and locally bred sweet potato (Ipomoea batatas) genotypes across multi-agro ecological zones in Nigeria. Proceeding of the $47^{\text {th }}$ Annual Conference of Agricultural Society of Nigeria, Ibadan.

[8] Chude V.O., Olayiwola S.O., Osho, A.O., Daudu, C.K. (2011). Fertilizer use and management practices for Crops in Nigeria produced by federal fertilizer department federal ministry of agriculture and rural development, Abuja. December, 2011

[9] Genstat (2012). Release 10.3DE (P/C Windows Nov 2012) 16.06.34. Copyright 2011VSN International limited. (Rothermstead Experimental station).

[10] Hector, V., Steven, F. Alton, A. (2010). Sweet potato production guide lines for Haiwai.

[11] Onunka (2010) Agronomy of sweet potato: In Yam, Cocoyam, Sweet potato and post-harvest management. Edited by Ukpabi, U.J., and K. I Nwosu pp207-214. 